\title{
Effect of Onions on Blood Fibrinolytic Activity
}

\author{
I. SUDHAKARAN MENON, ${ }^{*}$ M.B. ; R. Y. KENDAL, $\dagger$ M.B. ; H. A. DEWAR, $\ddagger$ M.D., F.R.C.P. \\ D. J. NEWELL,§ M.A., PH.D.
}

Brit. med. F., 1968, 3, 351-352

\begin{abstract}
Summary: Twenty-two convalescent patients at rest were given a fat-enriched breakfast with and without the addition of $60 \mathrm{~g}$. of fried or boiled onions. Both forms of onions were found to prevent the expected decrease in fibrinolytic activity, and indeed the latter was actually increased.
\end{abstract}

\section{Introduction}

A casual remark by a patient that in France when a horse develops clots in the legs it is treated by a diet of garlic and onions led one of us (I.S.M.) to investigate onions as a possible source of a fibrinolytic agent. A search of the medical literature led to the discovery of an investigation of Indians residing in India which showed that fibrinolytic activity was significantly reduced after a fat-enriched meal (Gupta et al., 1966). Similar results have been obtained in other countries (Greig and Runde, 1957 ; Billimoria et al., 1959 ; Mehrotra et al., 1966 ; Moser and Hajjar, 1966 ; Menon, 1967a). Ingestion of fried onions not only prevented this reduction in fibrinolytic activity but produced a significant increase of it in the blood stream (Gupta et al., 1966). The investigation described here was undertaken in order to study the effect of onions on the fibrinolytic activity of Britons.

\section{Subjects and Methods}

Twenty-two ambulant patients aged 19 to 78 years were selected for study. They were convalescing from bleeding peptic ulcer, were free of symptoms, and were not on any drug therapy at the time of examination.

After fasting samples of blood were collected from all patients for the estimation of fibrinolytic activity, cholesterol, recalcified clotting-time, thrombotest, and fibrinogen titre. The patients were divided into two groups.

Group 1 (14 patients).-After withdrawal of the samples mentioned the first seven patients were given a breakfast containing $98 \mathrm{~g}$. of fat at 9.30 a.m. and new samples of blood were collected after two and three hours. The procedure was repeated the following day, but this time $60 \mathrm{~g}$. of fried onions were added to the meal. For the remaining seven patients the routine was reversed and they were given the fried onions with their breakfast on the first day.

Group 2 (8 patients).-The method was identical to that outlined above, the only difference being that four patients in this group had boiled onions with their breakfast on the first day and none on the second. The opposite was the case with the remaining four patients.

All the 22 subjects were kept in bed throughout the experiment, since a previous study had shown that moderate exercise increases fibrinolytic activity (Menon, 1966a; Menon et al., 1967). Smoking was not permitted.

Euglobulin lysis time was estimated by von Kaulla's method (1963), slightly modified as previously described (Menon and

\footnotetext{
- Research Fellow, Department of Medicine.

+ House-physician, Department of Medicine.

Physician and Cardiologist, Department of Medicine.

Professos of Medical Statistics.

Royal Victoria Infirmary and the University of Newcastle upon Tyne, Newcastle upon Tyne.
}

Dewar, 1967). The fibrinolytic activity has been derived from these lysis times and expressed in units by multiplying the reciprocal of these lysis times in minutes by 10,000. Fibrinogen titre was measured by the method of Schneider (1952), which gives a rough guide to the fibrinogen level inside the body. Cholesterol levels, recalcified clotting-times, and thrombotests were estimated by standard methods.

\section{Results}

Tables I, II, and III show the fibrinolytic activity of the two groups of patients. The results show that after ingestion of a fat-enriched breakfast a decrease of fibrinolytic activity

TABLB I.-Effect of Fried Onions on Fibrinolytic Activity

\begin{tabular}{|c|c|c|c|c|c|c|}
\hline & \multicolumn{6}{|c|}{ Euglobulin Lysis Time (in Units) } \\
\hline & \multicolumn{3}{|c|}{ Breakfast Only } & \multicolumn{3}{|c|}{ Breakfast + Onions } \\
\hline & 9 a.m. & |11.30 a.m. & 12.30 p.m. & 9 a.m. & 11.30 a.m. & 12.30 p.m. \\
\hline $\begin{array}{r}1 \\
2 \\
3 \\
4 \\
5 \\
6 \\
7 \\
8 \\
9 \\
10 \\
11 \\
12 \\
13 \\
14\end{array}$ & $\begin{array}{r}57 \cdot 1 \\
62 \cdot 5 \\
41 \cdot 6 \\
105 \cdot 0 \\
27 \cdot 7 \\
50 \cdot 0 \\
44 \cdot 4 \\
20.8 \\
23 \cdot 8 \\
26 \cdot 6 \\
71 \cdot 4 \\
83.3 \\
20.8 \\
23.8\end{array}$ & $\begin{array}{l}50.0 \\
48.7 \\
27.7 \\
35.7 \\
23.8 \\
35.7 \\
33.3 \\
20.4 \\
25.0 \\
25.0 \\
76.9 \\
66.6 \\
20.0 \\
25.0\end{array}$ & $\begin{array}{l}48 \cdot 7 \\
46.5 \\
28.9 \\
37.0 \\
23.8 \\
44.4 \\
34.4 \\
21.2 \\
22.7 \\
24 \cdot 0 \\
54.0 \\
62.5 \\
20.4 \\
22 \cdot 7\end{array}$ & $\begin{array}{l}86.9 \\
66.6 \\
33.3 \\
86.9 \\
30.3 \\
26.3 \\
60.6 \\
12.8 \\
55.5 \\
23.2 \\
33.8 \\
31.7 \\
18.5 \\
27.7\end{array}$ & $\begin{array}{l}90.9 \\
86.9 \\
41.6 \\
90.9 \\
40.8 \\
76.9 \\
71 \cdot 4 \\
41.6 \\
71.4 \\
35.0 \\
74.0 \\
64.5 \\
34.4 \\
34.4\end{array}$ & $\begin{array}{r}100 \cdot 0 \\
90.9 \\
41.6 \\
95.2 \\
40.0 \\
74.0 \\
66.6 \\
38.4 \\
76.9 \\
31.7 \\
83.3 \\
66.6 \\
33.3 \\
33.3\end{array}$ \\
\hline Mean & $47 \cdot 1$ & 36.7 & $35 \cdot 1$ & $42 \cdot 4$ & $61 \cdot 1$ & $62 \cdot 3$ \\
\hline
\end{tabular}

TABLE II.-Effect of Builed Onions on Fibrinolytic Activity

\begin{tabular}{l|c|c|c|c|c|c}
\hline & \multicolumn{6}{c}{ Buglobulin Lysis Time (in Units) } \\
\cline { 2 - 7 } & \multicolumn{3}{|c|}{ Breakfast Only } & \multicolumn{3}{c}{ Breakfast + Onions } \\
\cline { 2 - 7 } & 9 a.m. & 11.30 a.m. & 12.30 p.m. & 9 a.m. & 11.30 a.m. & 12.30 p.m. \\
\hline 15 & 55.5 & 41.6 & 43.4 & 31.2 & 66.6 & 83.3 \\
16 & 57.1 & 60.6 & 55.5 & 54.0 & 74.0 & 74.0 \\
17 & 38.4 & 34.4 & 33.8 & 34.4 & 50.0 & 55.5 \\
18 & 76.9 & 66.6 & 68.9 & 83.3 & 11.1 & 117.6 \\
19 & 27.7 & 25.0 & 25.0 & 25.6 & 41.6 & 41.6 \\
20 & 47.6 & 38.4 & 36.3 & 50.0 & 68.9 & 66.6 \\
21 & 32.2 & 27.7 & 28.5 & 41.6 & 50.0 & 50.0 \\
22 & 50.0 & 38.4 & 40.0 & 55.5 & 83.3 & 76.9 \\
\hline Mean & 48.2 & 41.6 & 41.4 & 47.0 & 68.2 & 70.7 \\
\hline
\end{tabular}

TABLB III.-Fibrinolytic Activity and the Effect of Onions

\begin{tabular}{|c|c|c|c|c|}
\hline & \multicolumn{2}{|c|}{ Group 1 (14 Patients) } & \multicolumn{2}{|c|}{ Group 2 (8 Patients) } \\
\hline & $\begin{array}{c}\text { Breakfast } \\
\text { Only }\end{array}$ & $\begin{array}{c}\text { Breakfast } \\
\text { and Fried } \\
\text { Onions }\end{array}$ & $\begin{array}{c}\text { Breakfast } \\
\text { Only }\end{array}$ & $\begin{array}{l}\text { Breakfast } \\
\text { and Boiled } \\
\text { Onions }\end{array}$ \\
\hline $\begin{array}{l}\text { Mean E.L.T. } 9 \text { a.m. } \\
\text { Mean E.L.T. } 11.30 \text { a.m. } \\
\text { Mean change } 9-11.30 \text { a.m. } \\
\text { S.E. of mean change } \\
\text { Significance of } \text { mean } \\
\text { change } \\
\text { ch }\end{array}$ & $\begin{array}{c}47 \cdot 1 \\
36.7 \\
-10.4 \\
\pm 4.9 \\
P<0.055\end{array}$ & $\begin{aligned} 42.4 \\
61.1 \\
+18.7 \\
\pm 3.8 \\
P<0.001\end{aligned}$ & $\begin{array}{c}48.2 \\
41.6 \\
-6.6 \\
\pm 2.0 \\
P<0.02\end{array}$ & $\begin{array}{r}47 \cdot 0 \\
68 \cdot 2 \\
+21 \cdot 2 \\
\pm 3 \cdot 0 \\
P<0.001\end{array}$ \\
\hline 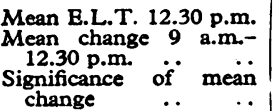 & $\begin{array}{c}35.1 \\
-12.0 \\
P<0.05\end{array}$ & $\begin{aligned} & 62.3 \\
+ & 19.9 \\
P & <0.001\end{aligned}$ & $\begin{array}{c}41.4 \\
-6.8 \\
P<0.01\end{array}$ & $\begin{aligned} & 70.7 \\
+ & 23.7 \\
P & <0.001\end{aligned}$ \\
\hline
\end{tabular}

All comparisons are made on a "within-patient" basis: individual changes (e.g.) from 9 to $11.30 \mathrm{Lm}$.) were calculated for each patient, and standard errors 
occurs. The addition of onions, whether fried or boiled, not only prevented this reduction but also caused a marked increase. Recalcified clotting-times, thrombotests, and cholesterol and fibrinogen levels were not significantly changed (Table IV).

TABLE IV.-Mean Values of Recalcified Clotting-times (R.C.T.) Thrombotest, Cholesterol, and Fibrinogen With and Without Fried Onions (22 Patients)

\begin{tabular}{|c|c|c|c|c|c|c|}
\hline & \multicolumn{3}{|c|}{$\begin{array}{l}\text { Ordinary } \\
\text { Breakfast }\end{array}$} & \multicolumn{3}{|c|}{$\begin{array}{c}\text { Ordinary Breakfast } \\
\text { Plus Onions }\end{array}$} \\
\hline & 9 a.m. & 11.30 a.m. & 12.30 p.m. & 9 a.m. & 11.30 a.m. & 12.30 p.m. \\
\hline $\begin{array}{l}\text { R.C.T. (seconds) } \\
\text { Thrombotest }(\%)\end{array}$ & $\begin{array}{l}87 \cdot 8 \\
80 \cdot 1\end{array}$ & $\begin{array}{l}88 \cdot 4 \\
81 \cdot 2\end{array}$ & $90 \cdot 2$ & $\begin{array}{l}91 \cdot 9 \\
82 \cdot 2\end{array}$ & $\begin{array}{l}92 \cdot 3 \\
81 \cdot 8\end{array}$ & $92 \cdot 1$ \\
\hline Fibrinogen $\left\{\begin{array}{l}\mathbf{D} \\
\mathbf{E} \\
\mathbf{F} \\
\mathbf{G} \\
\mathbf{H}\end{array}\right.$ & $\begin{array}{c}220 \cdot 7 \\
2 \\
6 \\
5 \\
8 \\
1\end{array}$ & $\begin{array}{l}- \\
3 \\
3 \\
9 \\
5 \\
2\end{array}$ & $\begin{array}{c}216 \cdot 7 \\
3 \\
2 \\
8 \\
5 \\
4\end{array}$ & $\begin{array}{c}212 \cdot 5 \\
2 \\
3 \\
7 \\
8 \\
2\end{array}$ & $\begin{array}{r}- \\
0 \\
5 \\
5 \\
10 \\
2\end{array}$ & $\begin{array}{c}219 \cdot 8 \\
2 \\
1 \\
7 \\
4 \\
8\end{array}$ \\
\hline
\end{tabular}

\section{Discussion}

The results confirm the findings of Gupta et al. (1966) that the addition of onions to a fat-enriched meal not only prewents the expected reduction in fibrinolytic activity caused by such a diet but actually promotes significant increase of it in every patient $(P<0.001)$. The results also indicate that the factor responsible is not only heat-stable but probably not watersoluble.

Undoubtedly there is a need for some substance which will have this effect on fibrinolytic activity in relation to fatty foods. We already have adequate agents for the prevention and treatment of excessive fibrinolytic activity-for example, aminocaproic acid, para-aminomethylbenzoic acid, and Trasylol (Okamoto and Okamoto, 1962; New Engl. F. Med., 1965; Menon, 1967b). Most of the agents potent in enhancing the fibrinolytic activity are, however, antigenic (for example, streptokinase), very expensive (for example, urokinase), or transient in effect (for example, nicotinic acid), and in any case only effective parenterally (Tillet et al., 1955; Weiner ct al., 1958 ; Celander and Guest, 1960 ; Menon, 1966b). Research has been carried out in the hope of discovering a cheap nonantigenic drug (Menon, 1967c). Fearnley et al. (1967) investigated the oral antidiabetic group of drugs, sulphonylureas and diguanides, and found metformin to be the most effective as well as the best tolerated.

Onions are known to be composed of essential oils, allypropyl, disulphide, catechols, thioproprione aldehyde, protocatechuic acid, thiocyanates, as well as some calcium, phosphorus, iron and vitamins (Wealth of India, 1948 ; Paech and Tracey, 1955 ; Chopra et al., 1956). Whether the increased fibrinolytic activity in the blood is caused by one of these or by a hitherto unknown component of the onion has not yet been established, though investigations are in progress to clarify this.

Our thanks are due to Professor A. G. Heppleston and Professor A. L. Latner for assistance with the study, to Mrs. D. Weightman for statistical help, and to Sister R. Watkins and Sister M. J. O. Freeman for their careful supervision of the diet. We are also indebted to Mr. Alan Martin for technical assistance and to Mrs. M. Jackson, our Editor of Research Publications, for invaluable editorial help.

\section{REFERENCES}

Billimoria, J. D., Drysdale, J., James, D. C. O., and Maclagan, N. F. (1959). Lancet, 2, 471.

Celander, D. R. and Guest, M M (1960). Amer, 7. Cardiol., 6, 409.

Chopra, R. N., Nayar, S. L., and Chopra, I. C. (1956). G̈lossary of Indian Plants, p. 11. New Delhi.

Fearnley, G. R., Chakrabarti, R., Hocking, E. D., and Evans, J. F. (1967). Lancet, 2, 1008.

Greig, H. B. 'W., and Runde, I. A. (1957). Lancet, 2, 461.

Gupta, N. N., Mehrotra, R. M. L., and Sircar, A. R. (1966). Indian f. med. Res., 54, 48.

Mehrotra, R. M. L., Gupta, N. N., and Mittal, S. P. (1966). Indian $\mathcal{F}$. med. Res., 54, 54.

Menon, I. S. (19668). Lancet, 2, 1365.

Menon, I. S. (1966b). Brit. F. clin. Pract., 20, 561

Menon, I. S. (1967a). Lab. Pract., 16, 469.

Menon, I. S. (1967a). Lab. Pract., 16, 469.

Menon, I. S. (1967b). Brit. F. clin. Pract., 21,

Menon, I. S. (1967c). Lab. Pract., 16, 1096.

Menon, I. S., and Dewar, H. A. (1967). Brit. med. F., 2, 613.

Moser, K. M., and Haijar, G. C. (1966). Amer. F. med. Sci., 251, 536.

New Engl. ₹. Med., 1965, 273, 336

Okamoto, S., and Ökamoto, U. (1962). Keio f. Med., 11, 105.

Paech, K., and Tracey, M. V. (editors) (1955). Modern Methods in Plant Analysis, p. 714. Berlin.

Schneider, C. L. (1952). Amer. 7. Obstet. Gynec., 64, 141.

Tillet, W. S. Johnson, A. J., and McCarty, W. R. (1955). $\dot{f}$. clin. Invest., 34, 169.

von Kaulla, K. N. (1963). Chemistry of Thrombolysis : Human Fibrinolyric Enzymes, p. 79. Springfield, Illinois.

Wealth of India, 1948, 1, 56. New Delhi.

Weiner, M., Redisch, W., and Steele, J. M. (1958). Proc. Soc. exp. Biol. (N.Y.), 98, 755 .

\title{
Experience with a Hepatitis-free Plasma Protein Solution
}

\author{
A. J. SALSBURY,* M.D. ; M. BROZOVICH,* M.D.
}

\footnotetext{
Summary : Clinical experience with a $4.3 \%$ solution of $S$ plasma protein treated to render it free of the agent of serum hepatitis is satisfactory. Sixty-seven transfusions of $400 \mathrm{ml}$. of the commercial preparation were given to 33 patients ( 25 with acute blood loss, 4 with severe burns, and 4 with hypoproteinaemia secondary to hepatic or renal disease).

The solution was clinically as effective as reconstituted dried plasma in expanding plasma volume and in replacing serum protein lost in burns. Adverse effects were mild pyrexial reactions in one case and facial flushing in another. No cases of serum hepatitis occurred.

The solution is available for immediate use, it can be kept at room temperature, and, as it does not cause rouleaux formation, it can be given before blood is taken for grouping and cross-matching.
}

\section{Introduction}

The value of reconstituted dried plasma in the restoration of blood volume by transfusion is well proved. Unfortunately such transfusion carries a slight but definite risk of transmission of disease, serum hepatitis presenting the greatest problem. The incidence of serum hepatitis after transfusion of plasma has been estimated as less than $1 \%$ in "small-pool" plasma (Medical Research Council, 1954) and as high as $18 \%$ in "large-pool" plasma (Morgan and Williamson, 1943).

It was largely because of the risk of serum hepatitis in transfusion of plasma that synthetic plasma expanders, such as the 8 dextrans, were developed. Certain plasma fractions, particularly albumin, are also thought to be free from the agent causing serum hepatitis (Paine and Janeway, 1952).

* Department of Haematology, St. Bartholomew's Hospital, London
E.C.1. . 